Environment Conservation Journal 19 (3) 139-144, 2018

ISSN 0972-3099 (Print) 2278-5124 (Online)

Abstracted and Indexed

\title{
Preliminary study on inhibitory activity of Enterobacter $s p$. strain KD111 isolated from the Cow feces
}

\author{
Gupta Kartikey Kumar and Rana Deepanshu 龱
}

Received: 21.04 .2018

Revised: 28.07 .2018

Accepted: 14.09.2018

\begin{abstract}
The objective of the present study was to isolate Enterobacter sp. from the faecal matter of cow followed by its screening for antimicrobial activity against Gram-positive and Gram-negative bacteria having clinical importance. On the basis of morphological and biochemical characterisation of seven isolates obtained from cow dung sample, isolate KD111 was probably identified as Enterobacter sp. and screened for its inhibitory activity against 14 test organisms comprising both Gram-positive and Gram-negative types using cross-streak method, in which both i.e. test organisms and isolates were streaked perpendicularly on nutrient agar plates followed by measurement of inhibition zone between the streaks after incubation. The preliminary screening revealed significant antimicrobial activity of Enterobacter sp. against Salmonella typhi (MTCC 3216), Escherichia coli, Staphylococcus aureus (MTCC 7443) and Bacillus cereus (MTCC 6728) with highest inhibition against Salmonella typhi (MTCC 3216) and Bacillus cereus (MTCC 6728). Our results indicate that Enterobacter sp. may act as a producer of bioactive antimicrobial metabolites and therefore should be analysed further for its possible application as therapeutic agent.
\end{abstract}

Key words: Enterobacter sp., Cross-streak method, Antagonistic activity, Cow dung

\section{Introduction}

Microbial secondary metabolites are chemical use of antibiotics that pose serious health compounds produced naturally by the implications on patient care in terms of increasing microorganisms during idiophase which ensure their survival in a competing environment by regulating growth processes, replications and inhibiting life cycle of other microbes. Presence of these metabolites in the microbial extracts have played a major role in the development of new antimicrobial drugs (Kleinkauf and Dohren, 1990; Higgs et al., 2001; Esikova et al., 2002; Berdy, 2005; Ilic et al., 2007; Gupta and Rana, 2016). Secondary metabolites from many microorganisms have been successfully developed and produced up to commercial level in the form of antibiotics such as Gramicidin and Rifampin being produced by Bacillus and Streptomyces spp. respectively (Waites et al., 2008; Awais et al., 2010; Mahajan and Balachandran, 2012; Gupta and Rana, 2017). Pathogens are continually becoming resistant towards antibiotics, however, this problem is further increased by continuous and independent

\section{Author's Address}

Department of Botany and Microbiology, Gurukula Kangri University, Haridwar-249404, Uttarakhand, India.

E-mail.: rana.deepu91@gmail.com substantial morbidity and mortality (Maataoui et al., 2014; Balachandran et al., 2015; Gay et al., 2017; Ekwanzala et al., 2018). Resistance towards third-generation cephalosporins and monobactams (aztreonam) is evident by production of ESBL which have the ability to hydrolyze them. Thus emergence of drug resistant pathogens is a major concern in both hospitals and at community level resulting in an alarming scarcity of new antibiotics (Singh et al., 2014). At present, the researchers are trying to screen microorganisms from unexplored habitats in order to isolate microbes with new antimicrobial properties (Watve et al., 2001; Hozzein et al., 2011; Khanna et al., 2011; Wadetwar and Patil, 2013; Maataoui et al., 2014).

As per literature, many bacteria isolated from soil for example Bacillus lentus, Micrococcus roseus, Enterobacter aerogenes, Bacillus pumillus, Bacillus alvei and Bacillus amylolquefaciens have shown bioactivity against Shigella spp., Staphylococcus aureus, Pseudomonas spp., Proteus spp., Corynebacterium diphtheriae, Streptococcus pneumonia, Salmonella group D, and Vibrio

Copyright by ASEA

139

All rights of reproduction in any form reserved 
parahaemolyticus (Abdulkadir and Waliyu, 2012; Boottanun et al., 2017). Therefore, screening microorganisms from new or less exploited sources with reference to antimicrobial metabolite production may provide new leads for drug discovery.

Ruminant animals have stable microbial ecological balance system and are rich in microbial diversity (Li et al., 2018). Cow dung is a bovine excreta generated after the digestion of consumed food materials containing crude fibre, crude protein, cellulose and various types of macro $(\mathrm{N}, \mathrm{K}, \mathrm{S})$, and micro nutrients such as traces of $\mathrm{P}, \mathrm{Fe}, \mathrm{Co}, \mathrm{Mg}, \mathrm{P}$, $\mathrm{Cl}$ and $\mathrm{Mn}$ (Nene, 1999). Cow dung micro-flora is usually diverse containing abundant number of Bacilli, Lactobacilli and Cocci and some identified and unidentified fungi and yeasts (Muhammad and Amusa, 2003). Various microorganisms such as Lactobacillus plantarum, Lactobacillus casei, Lactobacillus acidophilus, Bacillus subtilis, Enterococcus diacetylactis have been reported earlier from lower part of the gut of the cows (Ware et al., 1998). Other than these, Bacillus, Bifidobacterium and yeasts are also present in the rumen of the cow for better rumen fermentation (Kung, 2004; Yang et al., 2017). Antifungal substances isolated from cow dung inhibit the growth of coprophilous fungi (Dhama et al., 2005; Joseph and Sankarganesh, 2011; Dhama et al., 2013). Eupenicillium bovifimosum, that produces patulodine-like compounds viz. CK2108A and CK2801B was also isolated from cow dung (Dorothy and Frisvad, 2002). Laukova et al., (1998) isolated Enterococcus faecalis V24 from cow dung that produced a heat stable, largely hydrophobic antimicrobial substance possessing antimicrobial activity against pathogenic Gram-negative bacteria. Similarly Teo and Teoh (2011) also isolated a strain from cow dung i.e. K4 showing antibacterial activity against Escherichia coli. Therefore, in the present work, considering all these facts, an attempt has been made to determine antagonistic activity of Enterobacter sp. from the gut of cow by collecting cow dung samples.

\section{Material and Methods}

Sample collection: Dung sample of desi cow (breed Gaolao) was collected from Saharanpur. Sample was collected aseptically in sterile container and analysed immediately after transporting to the laboratory (Yang et al., 2017).

Isolation of Bacterial Species: For isolation purpose, serial dilution technique was employed in which $1 \mathrm{~g}$ of cow dung was mixed in $9 \mathrm{ml}$ of sterile saline $(0.85 \%)$ and dilutions were made from $10^{-2}$ to $10^{-8}$. Aliquot $(0.1 \mathrm{ml})$ from each dilution was spread on Nutrient Agar Medium (NAM) followed by incubation at $37^{\circ} \mathrm{C}$ for $24-48 \mathrm{~h}$. Different bacterial colony were selected and purified by repeated streak plate method. Until further use, the slants were kept at $4^{\mathrm{O}} \mathrm{C}$ (Sawant et al., 2007; Das, 2010).

Morphological and Biochemical characterization: Morphological and Biochemical characterization of all the seven isolates was done in order to determine Enterobacter spp. Morphological characterization (Gram-staining) was undertaken as described by Beveridge (2001). Biochemical characterization was performed according to the criteria given in Bergey's Manual of Determinative Bacteriology (Holt et al., 1994).

Detection of inhibitory activity of Enterobacter sp.: Antmicrobial activity of the isolated Enterobacter $s p$. designated as KD111 was evaluated using cross-streak method (Gupta and Rana, 2017) against 14 test organisms i.e., Vibrio cholerae (MTCC 3904), Salmonella typhi (MTCC 3216), Salmonella typhimurium (MTCC 3231), Escherichia coli (clinical isolate), Escherichia coli (MTCC 118), Staphylococcus aureus (MTCC 7443), Staphylococcus aureus (MTCC 3160), Bacillus subtilis (MTCC 441), Bacillus cereus (MTCC 6728), Proteus vulgaris (MTCC 426), Enterococcus faecalis (MTCC 439), Pseudomonas aeruginosa (MTCC 424), Shigella flexneri (MTCC 1457), and Streptococcus pyogenes (MTCC 442). Enterobacter sp. KD111 was streaked onto NAM plates as a single streak in the centre and incubated at $37^{\circ} \mathrm{C}$ for $24 \mathrm{~h}$. The plates were then reinocluated with each test organism as a single streak perpenducluar to the Enterobacter sp. KD111. The microbial inhibitions were observed after $24 \mathrm{~h}$ by measuring the distance of the inhibition zone between KD111 and test organisms.

\section{Results and discussion}

Isolation and morphological characterization of gut bacteria: In the present study, seven isolates of 
gut from cow were isolated from the cow dung sample by serial dilution method. Morhphological characterisation of seven isolates revealed only KD111 to be Gram-negative rod while others were found to be Gram-positive cocci (KD112, KD113 and KD114), Gram-positive rod (KD115 KD116) and Gram-negative cocci (KD117). Therefore, KD111 was selected for biochemical charcterisation regarding identification of Enterobacter sp. Detailed results of morphological characterization are summarised in the Table 1.

Table 1. Morphological analysis of the bacterial isolates.

\begin{tabular}{|l|l|l|}
\hline $\begin{array}{l}\text { Isolates } \\
\text { /Investigation }\end{array}$ & Gram Reaction & Shape \\
\hline KD111 & Gram-negative & Rod \\
\hline KD112 & Gram-positive & Cocci \\
\hline KD113 & Gram-positive & Cocci \\
\hline KD114 & Gram-positive & Cocci \\
\hline KD115 & Gram-positive & Rod \\
\hline KD116 & Gram-positive & Rod \\
\hline KD117 & Gram-negative & Cocci \\
\hline
\end{tabular}

Biochemical characterization of isolate KD111: Apart from being motile, and positive for amylase as well as catalse production, our isolate KD111 could also able to utilise glucose, lactose, sucrose and citrate as carbon source. Therefore, isolate KD111 was identified as Enterobacter sp. (Holt et al., 1994). Results of biochemical characters are comprised in the Table 2.

Table 2. Biochemical characterisation of the bacterial isolate KD111.

\begin{tabular}{|l|l|}
\hline Test/Isolates & KD111 \\
\hline Motility & Motile \\
\hline Glucose Fermentation & + \\
\hline Lactose Fermentation & + \\
\hline Sucrose Fermentation & + \\
\hline Gelatine Liquification & - \\
\hline Starch Hydrolysis & + \\
\hline Indole & + \\
\hline Methyl-Red & - \\
\hline Vogeus-Proskeur & - \\
\hline Citrate Utilisation & + \\
\hline Catalase Production & + \\
\hline Oxidase & - \\
\hline Urease & - \\
\hline
\end{tabular}

Inhibitory activity of Enterobacter sp. by crossstreak method: Out of seven isolated bacteria, KD111 was identified as Enterobacter $s p$. and subjected to antagonistic activity by cross-streak method against a panel of test bacteria having medical importance. Among test organisms include Salmonella typhi that causes Typhoid and paratyphoid fever (Hsiao et al., 2016) and Escherichia coli, which is responsible for urinary tract infection, food poisoning and diarrhoea (Alteri et al., 2009; Teo and Teoh, 2011). Isolate KD111 demonstrated significant antimicrobial activity as evident by the inhibition of seven out of fourteen test organisms. Maximum inhibition was recorded against Salmonella typhi $(8.0 \mathrm{~mm})$, Salmonella typhimurium $(8.0 \mathrm{~mm})$ and Bacillus cereus $(8.0$ $\mathrm{mm})$, while minimum $(3.0 \mathrm{~mm})$ was against both strains of Staphylococcus aureus (Table-3).

Isolate KD111 inhibited both Gram-positive and Gram-negative test organisms, thereby indicating the secretion of broad spectrum antimicrobial agents. The difference in the sensitivity of Grampositive and Gram-negative bacteria against Enterobacter sp. strain KD111 may be due to the morphological differences in their outer membrane (Gebreyohannes et al., 2013). Qiu et al., (2017) stated that bacteria belonging to Enterobacteriaceae may revert the disrupted structure of the gut microbiota to stabilize diversity. Enterobacter aerogenes isolated from orchard soil have shown significant in vitro antagonistic activity against several plant pathogens as reported by Utkhe and Sholberg (1986). One important observation of KD111 was made against Escherichia coli, when $5.0 \mathrm{~mm}$ inhibition was recorded. However, still antimicrobial activity of Enterobacter spp. is not well reported in the literature but other researchers have shown similar findings by using different producer organisms. Abdulkadir and Waliyu (2012) isolated Bacillus lentus and Bacillus alvei isolated from soil showing antibacterial activity against Staphylococcus aureus. Bacitracin, a commercially available antibiotic produced by Bacillus $s p$. inhibits Escherichia coli and Staphylococcus aureus (Prescott et al., 2008). Enterococcus faecium isolated from traditional rigouta cheese was also found effective against Staphylococcus aureus (Ghrairi et al., 2008). Bacillus species isolated from cow dung showed significant antimicrobial effect 
against Vibrio Cholerae (MTCC 3904), Salmonella typhi (MTCC 3216), Escherichia coli, and Bacillus cereus (MTCC 6728) (Gupta and Rana, 2017). Gupta and Rana (2018), observed inhibitory activity of Alcaligenes fecalis and Alcaligenes latus isolated from cow dung against Salmonella typhi, Escherichia coli and Bacillus subtilis (MTCC 441). Antibiotic resistance among clinical pathogens for example, Salmonella typhi, Vibrio choleraee, Staphylococcus aureus, Escherichia coli and Bacillus cereus has been reported recently against not only $1^{\text {st }}$ and $2^{\text {nd }}$ generation antibiotics but also against $4^{\text {th }}$ generation antibiotics (Mare and Coetzee, 1964; Alteri et al., 2009; Puah et al., 2016; Uppal et al., 2017).

\section{Conclusion}

Isolated strain Enterobacter sp. KD111 possess potential for producing antimicrobial substances which might be effective against these disease causing bacteria. Although the genus Enterobacter is generally associated with hospital-acquired infections, however, their bioactive metabolites should be analysed further to confirm their possible application as therapeutic agent against bacterial species.

\section{References}

Abdulkadir, M. and Waliyu, S., 2012. Screening and isolation of the soil bacteria for ability to produce antibiotics. European Journal of Applied Sciences, 4(5):211-215.

Alteri, C.J., Smith, S.N. and Mobley, H.L., 2009. Fitness of Escherichia coli during urinary tract infection requires gluconeogenesis and the TCA cycle. PLoS Pathogens, $5(5): 1-13$.
Awais, M., Pervez, A., Yaqub, A., and Shah, M.M., 2010. Production of antimicrobial metabolites by Bacillus subtilis immobilized in polyacrylamide gel. Pakistan Journal of Zoology, 42(3):267-275.

Balachandran, C., Duraipandiyan, V., Emi, N., and Ignacimuthu, S., 2015. Antimicrobial and cytotoxic properties of Streptomyces sp.(ERINLG-51) isolated from Southern Western Ghats. South Indian Journal of Biological Sciences, 1(1):7-14.

Bérdy, J., 2005. Bioactive microbial metabolites. The Journal of antibiotics, 58(1):1-26.

Beveridge, T.J., 2001. Use of the Gram stain in microbiology. Biotechnic \& Histochemistry, 76(3):111-118.

Boottanun, P., Potisap, C., Hurdle, J.G., and Sermswan, R.W., 2017. Secondary metabolites from Bacillus amyloliquefaciens isolated from soil can kill Burkholderia pseudomallei. AMB Express, 7(1):16.

Das, S., Ward, L.R. and Burke, C., 2010. Screening of marine Streptomyces spp. for potential use as probiotics in aquaculture. Aquaculture, 305(1-4):32-41.

Dhama, K., Chakraborty, S., and Tiwari, R., 2013. Panchgavya therapy (Cowpathy) in safeguarding health of animals and humans-a review. Research Opinions in Animal and Veterinary Sciences, 3(6):170-178.

Dhama, K., Rathore, R., Chauhan, R.S. and Tomar, S., 2005. Panchgavya (Cowpathy): an overview. International Journal of Cow Science, 1(1):1-15.

Dorothy, E.T., and Frisvad, J.C., 2002. Eupenicillium bovifimosum, a new species from dried cow manure in Wyoming. Mycologia, 94(2):240-246.

Ekwanzala, M.D., Dewar, J.B., Kamika, I., and Momba, M.N.B., 2018. Systematic review in South Africa reveals antibiotic resistance genes shared between clinical and environmental settings. Infection and drug resistance, 11:1907. 
Esikova, T.Z., Temirov, Y.V., Sokolov, S.L. and Alakhov, Y.B., 2002. Secondary antimicrobial metabolites produced by thermophilic Bacillus spp. strains VK2 and VK21. Applied Biochemistry and Microbiology, 38(3):226-231.

Gay, N., Belmonte, O., Collard, J.M., Halifa, M., Issack, M.I., Mindjae, S., Palmyre, P., Ibrahim, A.A., Rasamoelina, H., Flachet, L. and Filleul, L., (2017). Review of antibiotic resistance in the Indian Ocean Commission: A human and animal health issue. Frontiers in public health, 5:162.

Gebreyohannes, G., Moges, F., Sahile, S. and Raja, N., 2013. Isolation and characterization of potential antibiotic producing actinomycetes from water and sediments of Lake Tana, Ethiopia. Asian Pacific Journal of Tropical Biomedicine, 3(6):426-435.

Ghrairi, T., Frere, J., Berjeaud, J. M., and Manai, M., 2008. Purification and characterisation of bacteriocins produced by Enterococcus faecium from Tunisian rigouta cheese. Food Control, 19(2):162-169.

Gupta, K.K., and Rana, D., 2018. Bioactivity of Alcaligenes spp. isolated from cow dung against certain human pathogens. Environment Conservation Journal, 19(1\&2):59-64.

Gupta, K.K., and Rana, D., 2017. Evaluation of antagonistic activities of Bacillus spp. against certain bacteria of medical importance. Archives of Agriculture and Environmental Science. 2(4):353-356.

Gupta, K.K., and Rana, D., 2016. Antimicrobial Activity of Certain Bacterial Isolates-A Screening Study. Biotechnology International, 9(3):55-59.

Higgs, R.E., Zahn, J.A., Gygi, J.D., and Hilton, M.D., 2001. Rapid method to estimate the presence of secondary metabolites in microbial extracts. Applied and environmental microbiology, 67(1):371-376.

Holt JG, Krieg NR, Sneath PHA, Stanley JT, Williams ST. Bergey's Manual of Determinative Bacteriology. 9th ed. Williams and Wilkins Press: USA; 1994.

Hozzein, W.N., Rabie, W., and Ali, M.I.A., 2011. Screening the Egyptian desert actinomycetes as candidates for new antimicrobial compounds and identification of a new desert Streptomyces strain. African Journal of Biotechnology, 10(12):2295-2301.

Hsiao, A., Toy, T., Seo, H.J. and Marks, F., 2016. Interaction between Salmonella and Schistosomiasis: A Review. PLoS Pathogens, 12(12):1-12.

Ilic, S.B., Konstantinovic, S.S., Todorovic, Z.B., Lazic, M.L., Veljkovic, V.B., Jokovic, N. and Radovanovic, B.C., 2007. Characterization and antimicrobial activity of the bioactive metabolites in Streptomycete isolates. Microbiology, 76(4):421-428.
Joseph, B. and Sankarganesh, P., 2011. Antifungal efficacy of panchagavya. International Journal of Pharm Tech Research, 3(1):585-588.

Khanna, M., Solanki, R., and Lal, R. 2011. Selective isolation of rare actinomycetes producing novel antimicrobial compounds. International Journal of Advanced Biotechnology and Research, 2(3):357-75.

Kleinkauf, H., and Von Döhren, H., 1990. Review Nonribosomal biosynthesis of peptide antibiotics. In EJB Reviews 1990 (pp. 151-165). Springer, Berlin, Heidelberg.

Kung, J. L. (2004). Accessed on 10 February 2005. A direct fed microbes and enzyme for dairy cows. www.das.psu.edu/dairy nutrition/documents/kung.pdf.

Lauková, A., Czikková, S., Vasilková, Z., Juriš, P. and Mareková, M., 1998. Occurrence of bacteriocin production among environmental enterococci. Letters in Applied microbiology, 27(3):178-182.

Li, C., Wei, J., Jing, Y., Teng, B., Yang, P., Chen, X., Huang, H., Zhao, T., Che, T. and Zhang, C., 2018. A $\beta$ glucosidase-producing M-2 strain: Isolation from cow dung and fermentation parameter optimization for flaxseed cake. Animal Nutrition.

Maataoui, H., Iraqui, M., Jihani, S., Ibnsouda, S., and Haggoud, A. 2014. Isolation, characterization and antimicrobial activity of a Streptomyces strain isolated from deteriorated wood. African Journal of Microbiology Research, 8(11), 1178-1186.

Mahajan, G.B., and Balachandran, L., 2012. Antibacterial agents from actinomycetes-a review. Frontiers in Bioscience, 4(1):240-253.

Maré, I.J. and Coetzee, J.N., 1964. Antibiotics of Alcaligenes faecalis. Nature, 203(4943):430-431.

Muhammad, S., and Amusa, N.A., 2003. Invitro inhibition of growth of some seedling blight inducing pathogens by compost-inhabiting microbes. African Journal of Biotechnology, 2:161-164.

Nene, Y.L., 1999. Seed health in ancient and medieval history and its relevance to present-day agriculture. Asian AgriHistory (India).

Prescott, M.L., Harley, P.J. and Klein AD. Microbiology. 7th ed: Publishing Group; 2008.

Puah, S.M., Chua, K.H. and Tan, J.A.M.A., 2016. Virulence factors and antibiotic susceptibility of Staphylococcus aureus isolates in ready-to-eat foods: detection of $S$. aureus contamination and a high prevalence of virulence genes. International Journal of Environmental Research and Public Health, 13(2):199. 


\section{Gupta and Rana}

Qiu, L., Yang, D., Tao, X., Yu, J., Xiong, H., and Wei, H., (2017). Enterobacter aerogenes ZDY01 Attenuates Choline-Induced Trimethylamine N-Oxide Levels by Remodeling Gut Microbiota in Mice. Journal of microbiology and biotechnology, 27(8):1491-1499. Sawant, A.A., Hegde, N.V., Straley, B.A., Donaldson, S.C.,
Love, B.C., Knabel, S.J., and Jayarao, B.M., 2007. Antimicrobial-resistant enteric bacteria from dairy cattle. Applied and environmental microbiology, 73(1):156-163.

Singh, L.S., Sharma, H., and Talukdar, N.C., 2014. Production of potent antimicrobial agent by actinomycete, Streptomyces sannanensis strain SU118 isolated from phoomdi in Loktak Lake of Manipur, India. BMC microbiology, 14(1):278.

Teo, K.C. and Teoh, S.M., 2011. Preliminary biological screening of microbes isolated from cow dung in Kampar. African Journal of Biotechnology, 10(9):1640-1645.

Uppal, B., Mehra, B., Panda, P.S. and Kumar, S.K., 2017. Antimicrobial susceptibility profile of Vibrio choleraee strains isolated at a tertiary care medical centre in New Delhi, India. International Journal of Community Medicine And Public Health, 4(3):868-871.
Utkhede, R.S., and Sholberg, P.L., 1986. In vitro inhibition of plant pathogens by Bacillus subtilis and Enterobacter aerogenes and in vivo control of two postharvest cherry diseases. Canadian journal of microbiology, 32(12):963967.

Wadetwar, R.N., and Patil, A.T., 2013. Isolation and characterization of bioactive actinomycetes from soil in and around Nagpur. International Journal of Pharmaceutical Sciences, 4(4):1428-1433.

Waites, M.J., Morgan, N.L., Rockey, J.S. and Higton, M. (2008). Industrial Microbiology an Laboratory Practical's in Microbiol-ogy (Ist edition). Introduction, London, Blackwell Publisher.

Ware, D.R., Read, P.L., and Manfredi, E.T., 1998. Lactation performance of two large diary herds fed Lactobacillus acidophilus strain BT1386. Journal of Dairy Science, 71(Suppl 1):219-222.

Watve, M.G., Tickoo, R., Jog, M.M., and Bhole, B.D., 2001. How many antibiotics are produced by the genus Streptomyces? Archives of microbiology, 176:386-390.

Yang, J.H., Zhang, W.W., Zhuang, Y.Q., and Xiao, T., 2017. Biocontrol activities of bacteria from cow dung against the rice sheath blight pathogen. Journal of Plant Diseases and Protection, 124(2):131-141. 